\title{
Climbing Mount Everest: tackling the media at a regional level
}

\author{
Tom Harrison
}

\begin{abstract}
Regional Public Education Officers of the Royal College of Psychiatrists are strategically placed to influence and improve the coverage of mental health issues in the media. Their role needs to be enhanced and clarified, and a proposal is being put forward in the College to achieve this. One possible way of working locally is illustrated through the work of West Midlands Insight, which demonstrates the value of working with a wide group of people, including those who have experienced mental ill health.
\end{abstract}

There is much to be said in favour of modern journalism. By giving us the opinions of the uneducated, it keeps us in touch with the ignorance of the community.

Oscar Wilde

Media coverage of mental ill health issues is often distorted and stigmatising, occasionally it is atrocious. Most psychiatrists feel powerless to influence this, often because they believe that any intervention would be ineffectual, or misrepresented. It is proposed here that this need not necessarily be so. Through working with others, including those whose lives have been affected by psychiatric disorder, it is possible to influence the local press, and eventually change the climate of opinion within the media as a whole.

It comes as a surprise to many that most journalists and broadcasters actually wish to be well informed and present the issues in a reasonable manner. A headline is a marketing tool and editors sometimes change the overall meaning; however many provincial papers need copy, and will willingly print well-written articles. Local radio can provide opportunities for regular education and contributions to 'chat' programmes. Psychiatrists need to take advantage of these situations, in order to benefit their patients through reducing the ignorance of the community'.

\section{The Public Education Committee and Regional Public Education Officers}

In each geographic division of the College there are two or three Regional Public Education
Officers (RPEOs). Those known to the Public Education Committee were surveyed in 1995. Out of 26 questionnaires sent, 10 replies were received: of these one individual had held the post for over five years, five for over three years and two for less than six months. Two were unclear that they were still RPEOs.

In only one region had a public education strategy been formulated, and regular contacts with other RPEOs established. Three respondents were unclear about their role, and three more did not answer this particular question. The core activity reported was involvement with the media. However, other aspects of public education', such as working with schools, were not widely represented. A number commented on the lack of time to take up a more pro-active role.

It was clear that there was some confusion over the role of these College representatives. A proposal has now been put forward, through the Public Education Committee, to augment the numbers of RPEOs and to ensure that a strategy is developed in each region.

\section{West Midlands Insight: working with others}

One RPEO has inaugurated an organisation. West Midlands Insight, which is described here as a possible way forward. Its members include people who have experienced mental ill health, carers and a mixed group of professionals, and its aim is to improve media coverage of mental health issues.

It was formed in November of 1995, and holds monthly meetings. The attendance at these meetings can be rather fluid; but there is now a circulation list of nearly 40 members. Interest has been shown by three chief executives of trusts, one purchaser, and the local branches of Mind and National Schizophrenia Fellowship. A public relations company actively assists the group, and an 'independent' radio station operator is also a member. The most consistent support has come from a small group of 'survivors'.

The remit of the group is "To encourage the media to promote accurate and respectful 
messages about the issues of mental ill health", and it is planned to achieve this by:

(a) raising the issues and increasing the contact of informed people with media personnel,

(b) training of people in how to present their messages to the media.

(c) providing a point of contact for the media to obtain accurate information, and individuals to advise, or be interviewed, on current issues,

(d) monitoring the output of media in the West Midlands.

So far the group has organised some media training, and run a conference. This latter was very successful, bringing together over 100 people, with local Member of Parliament, $\mathrm{Dr}$ Lynne Jones, chairing the day. The regional branches of the National Schizophrenia Fellowship and Mind helped to sponsor the event, and provided speakers. Jeremy Dear, President of the National Union of Journalists, presented draft NUJ guidelines on reporting mental health issues. An editor, Peter Freeman of the Birmingham Evening Mail, challenged the audience to recognise the size of the task that they were taking on ("climbing Mount Everest!"), and to present their material succinctly and coherently. A further conference is planned for 1998, when a medal will be presented for the individual or group that has done most in 1997 to present positive images of mental ill health.

A procedure for monitoring the media is being developed, which will be used to assess programmes or articles. This can be done by individuals, or by groups summarising their findings. These views will be collected and presented to the media organs that produced the original material. Also this will provide a database of opinion, which can be used for research and analysis.

The RPEO has begun to develop a network of contacts with the local press and radio, circulating extracts of articles from the College journals and being asked advice on issues. Information is also being collected on other local initiatives. One psychiatrist is running a monthly 'phone-in' on local radio, another has been a member of a BBC monitoring group. One social services department for a while sponsored an exchange system between their staff and the local press.

Perhaps the most important aspect is the mutual support that the group provides to the members, and others, in recognising that 'Ever- est' can be climbed. That despite setbacks, by working together, it is possible to influence the media for the better.

\section{Conclusion}

It is possible, at the moment, for the media to misrepresent the problems of mental ill health, in a bigoted and offensive manner. The Press Complaints Commission appears unable to prevent this. A recent article declared: "Cops were right to take nut out" and further stated that such a person should be "weaving wicker baskets in a padded cell with only his pixies and demons to talk to" (Sunday Sport, 1996). This was found to be extremely derogatory and stigmatising by a group of that man's friends. The Press Complaints Commission replied to a letter of complaint arguing that the press is entitled to publish opinion even if it is offensive (Press Complaints Commission, 1997, personal communication). Clearly, had this been a matter of race or gender they would have had to take a different view.

West Midlands Insight is one of a number of organisations that are beginning to tackle this prejudice in the media; The Glasgow Media Group, MindLink, the Schizophrenia Media Agency, Presswise and Mental Health Media are all engaged in different ways in the same task. A network of regional groups could change the face of local media and gradually influence the national press. It would of course be a long and hard fought process; but it is achievable. Many journalists themselves are allies: the Scottish National Union of Journalists have produced a set of guidelines for reporting on these issues (Scottish Association for Mental Health, undated), and this lead is being followed by their colleagues in England and Wales.

\section{References}

SCOTTISH ASSOCIATION FOR MENTAL HEALTH (undated) Mental Health in the Media: A Good Practice Guide for Joumalists and Broadcasters. Edinburgh: Scottish Association for Mental Health.

SUNDAY SPORT (1996) Billy Britain, 24 November.

Tom Harrison, Consultant Psychiatrist in Rehabilitation, North Birmingham Mental Health Trust, Secretary West Midlands Insight, Malvern House, 71 Yardley Green Road, Bordesley Green, Birmingham B9 5QS 